\title{
Postmenopausal Breast Tuberculosis - Report of 4 Cases
}

\author{
Khalid Bouti Mouna Soualhi Karima Marc Rachida Zahraoui \\ Jouda Benamor Jamal Eddine Bourkadi Ghali Iraqi
}

Department of Respiratory Diseases, Moulay Youssef Hospital, Rabat, Morocco

\section{Keywords}

Breast · Lump · Tuberculosis · Menopause

\section{Summary}

Background: Breast tuberculosis is an uncommon disease even in countries where the incidence of tuberculosis is high. Case Report: This is a case series concerning 4 postmenopausal breast tuberculosis cases encountered in Moulay Youssef Hospital between January 2007 and December 2010. Breast tuberculosis represents $0.25 \%$ of all hospitalized tuberculosis patients in our department. The mean age of our patients was $62.5 \pm 5.8$ years. Clinical findings were heterogeneous; 1 case was multifocal tuberculosis, and another case was coexistent tuberculosis and malignancy of the breast. Mammography and ultrasonography findings were suspicious for malignancy in all 4 cases. Fine needle aspiration was negative in 3 cases. The diagnosis was made in all patients by histological examination of biopsy specimens, which revealed typical tuberculous lesions. Anti-tuberculosis therapy formed the mainstay of treatment. Conclusion: The clinical and radiological features of mammary tuberculosis can be very confusing and easily mistaken for breast cancer. Symptoms suggestive of tuberculosis warrant a biopsy to exclude possible cancer.

\section{Introduction}

Breast tuberculosis (TB) was first defined by Sir Astley Cooper in 1829 [1]. It is an extremely uncommon disease responsible for $0.025-1.04 \%$ of all breast pathologies [2]. Although breast TB is considered a disease of the developing world, a steady increase is also seen in developed countries.

\author{
Schlüsselwörter \\ Brust · Knoten · Tuberkulose - Menopause
}

\section{Zusammenfassung}

Hintergrund: Die Mammatuberkulose ist selbst in Ländern mit einer hohen Tuberkuloseinzidenz eine seltene Erkrankung. Fallbericht: Wir berichten eine Fallserie von 4 Patientinnen mit postmenopausaler Mammatuberkulose, die zwischen Januar 2007 und Dezember 2010 im Moulay Youssef Hospital vorstellig wurden. Die Brust ist bei $0,25 \%$ aller hospitalisierten Tuberkulosepatienten unserer Abteilung betroffen. Das mittlere Alter der 4 Patientinnen war 62,5 \pm 5,8 Jahre. Die klinischen Befunde waren heterogen. In einem Fall handelte es sich um multifokale Tuberkulose, in einem anderen Fall um eine gleichzeitig bestehende Tuberkulose und Tumorerkrankung der Brust. Die mammographische und die ultrasonographische Untersuchung deuteten in allen Fällen auf eine Tumorerkrankung hin. Die anschließende Feinnadelaspirationszytologie war bei 3 der Patientinnen negativ. Die Diagnose basierte bei allen Patientinnen auf der histologischen Untersuchung von Biopsieproben, welche typische tuberkulöse Läsionen ergab. Die antituberkulöse Therapie war Hauptbestandteil der Behandlung. Schlussfolgerung: Die klinischen und radiologischen Merkmale der Mammatuberkulose können sehr verwirrend sein und sind leicht mit Mammatumoren zu verwechseln. Symptome, die auf eine tuberlulöse Erkrankung hindeuten, sollten durch die Entnahme einer Biopsie zum Ausschluss einer möglichen Tumorerkrankung ergänzt werden.

It may be primary or secondary, and can be difficult to diagnose clinically as signs and symptoms can mimic breast cancer or abscess. This paper presents 4 cases which highlight that breast TB should be included in the differential diagnosis of breast lesions.

\section{KARGER \\ Fax +497614520714 \\ Information@Karger.de}

www.karger.com (c) 2012 S. Karger GmbH, Freiburg

$1661-3791 / 12 / 0075-0411 \$ 38.00 / 0$

Accessible online at:

www.karger.com/brc
Dr. Khalid Bouti

Department of Respiratory Diseases

Moulay Youssef Hospital

Rabat, Morocco

khalidbouti@gmail.com 


\section{Case Reports}

Case 1

A 56-year-old woman presented with a 3-months history of 2 lumps in her right breast, associated with mild pain, cough, dyspnea, fever, night sweats, loss of appetite, and weight loss. There was a family history of tuberculosis. On examination, she had 2 lumps in the lower quadrants of the right breast, as well as weak heart sounds and symptoms of pleural effusion. Mammography showed 2 spiculated mass lesions in both lower quadrants of the right breast, with thickening of the overlying skin. There was no microcalcification. Ultrasonography showed the lesions to have irregular margins, central necrotic areas with debris, and posterior enhancement. Fine needle aspiration (FNA) was inadequate, while examination of breast biopsy specimens showed necrotizing granulomas. Chest radiography revealed pleural effusion and a miliary pattern. A tuberculin skin test was carried out which was positive. Echocardiography showed discrete pericardial effusion. A diagnosis of multifocal TB was made, and the patient significantly improved after initiation of corticosteroid and anti-tuberculosis quadritherapy.

\section{Case 2}

A 63-year-old woman with type 2 diabetes and a personal medical history of tuberculosis presented with a 6-month history of a painful erythematous right breast lump and an associated sinus tract, accompanied by fever and weight loss. Examination revealed a lump in the upperouter quadrant of her right breast with nipple retraction. There also were 2 palpable lymph nodes in the right axilla. The tuberculin skin test was positive. Mammography showed asymmetric increased density in the right retroareolar area with some retraction of the nipple (fig. 1). Ultrasound of the right breast showed a $5 \times 5 \mathrm{~cm}$ lump with irregular margins and heterogeneous hypoechogenicity. Both trucut and fine needle biopsy were applied to the right breast lump. Pathological examinations showed chronic granulomatous inflammation with areas of central necrosis (fig. 2). The patient was placed on a regimen of antituberculosis quadritherapy with complete resolution of symptoms after 6 months.

\section{Case 3}

A 70-year-old woman presented with a painful lump in her right breast. Physical examination showed a lump of the lower-inner quadrant of the right breast. Mammography showed increased density in the right retroareolar area with some skin thickening of the areola and the nipple.
Foci of fine calcification were also noted. Ultrasonography showed a lump with irregular margins, hypoechoic heterogeneous echogenicity and microcalcifications, as well as enlargement of a right axillary lymph node. FNA was inadequate. A trucut biopsy confirmed an invasive ductal carcinoma of no special type along with evidence of non-necrotizing granulomatous inflammation. Subsequent Ziehl-Neelsen staining for acid fast bacilli confirmed a tuberculous etiology. The patient received antituberculosis therapy and underwent radical mastectomy with lymphadenectomy. Histological examination of the mastectomy specimen confirmed the coexistence of malignancy and tuberculosis.

\section{Case 4}

A 61-year-old woman with type 2 diabetes presented with a painful right breast lump and discharging sinus, associated with weight loss, fever, and night sweats. On examination, she had a lump in the upper-outer quadrant of her right breast. The tuberculin skin test was positive. Mammography showed asymmetric increased density in the right retroareolar area with some retraction of the nipple. Ultrasonography of the right breast showed a $5 \times 4 \mathrm{~cm}$ lump with irregular margins and thickening of the overlying skin. FNA was inadequate. A trucut biopsy showed non-necrotizing granuloma. The patient was placed on a regimen of anti-tuberculosis quadritherapy. On follow-up after 6 months, she was in reasonably good health.

\section{Discussion}

TB remains one of the leading causes of death from infectious diseases worldwide. Breast TB is one of its rarest forms. The first case was recorded by Sir Astley Cooper in 1829 who called it 'scrofulous swelling of the bosom' [3]. It comprises $3 \%$ of all breast diseases and is 5 times less common than carcinoma of the breast [4]. It can be classified as primary when no demonstrable tuberculous focus exists, or it can be secondary to a lesion elsewhere in the body $[5,6]$. Breast TB almost exclusively affects women and occurs mostly in multiparous lactating women between the ages of 20 and 40 years [7].

Our 4 cases were all menopausal women. The mean duration of symptoms was 4 months. A breast lump was the most common clinical presentation; homolateral axillary lymphade-

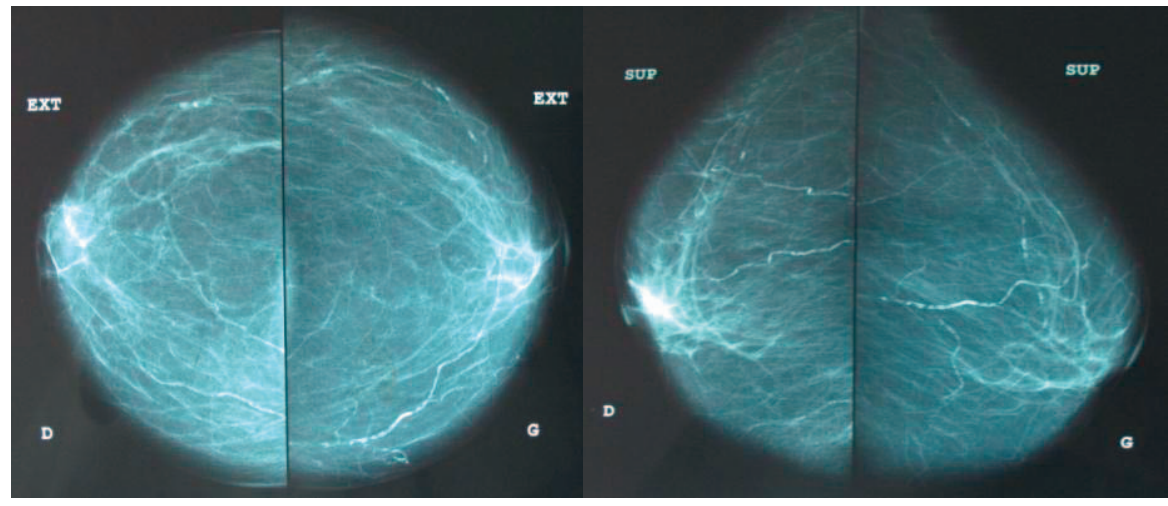

Fig. 1. Mammography showing increased density in the retroareolar area of the right breast.

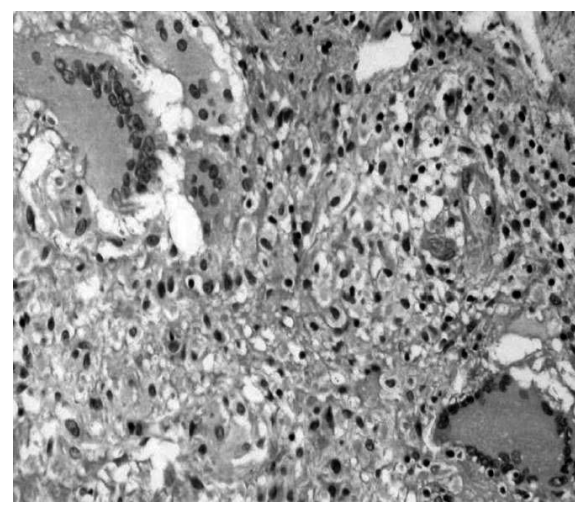

Fig. 2. Granuloma with epithelioid cells, Langhans' giant cells, and lymphocytes with areas of necrosis (H\&E stain, $\times 400)$. 
nopathy was seen in 1 case. All our patients had constitutional symptoms of tuberculosis such as fever, anorexia, failing health, weight loss, and night sweats.

Patients with breast TB usually have positive tuberculin skin tests [8]. Both breasts can be affected equally but bilateral involvement is very uncommon. Although the upperouter quadrant seems to be the most frequently involved site due to its proximity to the axillary nodes, any area of the breast can be affected. 3 patterns of breast TB have been described: nodular, diffuse, and sclerosing. The nodular variant is often misdiagnosed as fibroadenoma, fibroadenosis, malignancy, or breast abscess. The diffuse variety commonly leads to caseation and sinus formation. Sclerosing tuberculosis afflicts older women and is slow growing with the absence of suppuration [9]. It is generally thought that the breast gets involved in tuberculosis by retrograde lymphatic extension from the mediastinal, axillary, and cervical region [10]. On mammography, the nodular and diffuse forms mimic carcinoma. Ultrasonography shows echogenic masses, heterogeneous with altered echotexture, or a hypoechoic cystic lesion [11, 12]. Computed tomography and/or magnetic resonance imaging are useful in evaluating the relationship between deeply located lesions and the chest wall and pleura, and in detecting parenchymal lesions of the lung [9]. The diagnosis of breast tuberculosis is confirmed in $73 \%$ of patients on the basis of FNA cytology (FNAC) findings [13]. It is a rapid and noninvasive procedure that can be readily used especially in developing countries where other procedures may be unavailable [14]. Failure to demonstrate necrosis on FNAC does not exclude TB because of the small quantity of the sample examined. Core biopsy is more invasive than FNAC, requires more training and experience, and frequently requires imaging and guidance. Mycobacterium tuberculosis stain, culture, or polymerase chain reaction are not very sensitive, and this may cause some additional delays in the diagnosis.

It is important to remember that the recognition of $\mathrm{TB}$ does not exclude concomitant cancer. Other differential diagnoses include idiopathic granulomatous mastitis, sarcoidosis, Wegener's granulomatosis, giant cell arteritis, actinomycosis, and fat necrosis. Less common diseases are plasma cell mastitis, chronic pyogenic abscess, mammary dysplasia, fibroadenoma, and blastomycosis [10].

Anti-tuberculosis chemotherapy is still the main treatment for breast TB. Mastectomy is reserved for patients refractory to medical treatment [15]. Immunosuppressive conditions such as organ transplantation, human immunodeficiency virus infection, advanced age, and chronic diseases increase the chances of tuberculosis presenting atypically with extrapulmonary manifestations which can delay diagnosis and treatment. A high degree of clinical suspicion is necessary to ensure an early diagnosis. This motivated us to publish this case series to increase awareness among clinicians, enable prevention of diagnostic delays, and prevent unnecessary interventions and surgical procedures [10].

\section{Disclosure Statement}

None of the authors of this paper have any financial or personal conflicts of interest to disclose.

\section{References}

1 Cooper A: Illustration of the Diseases of the Breast. Part I. London, Longman, Rees, Orme, Brown and Green, 1829, p. 7.

2 Bani-Hani KE, Yaghan RJ, Matalka II, Mazahreh TS: Tuberculosis mastitis: a disease not to be forgotten. Int J Tuberc Lung Dis 2005;9:920-5.

3 Cooper A: Illustrations of the Diseases of the Breast, Part I. London, Longman, Rees, Orme, Brown and Green, 1829, p. 73.

4 Khanna R, Prasanna GV, Gupta P, Kumar M: Mammary tuberculosis: report on 52 cases. Postgrad Med J 2002;78:422-4.

5 Shinde SR, Chandawarkar RY, Deshmukh SP: Tuberculosis of the breast masquerading as carcinoma: a study of 100 patients. Word J Surg 1995;19:379-81.
6 Kakker S, Kapila K, Singh MK, et al.: Tuberculosis of the breast. A cytomorphologic study. ActaCytol 2000;44:292-6.

7 Elsiddig KE, Khalil EA, Elhag IA, et al.: Granulomatous mammary disease: ten years' experience with fine needle aspiration cytology. Int J Tuberc Lung Dis 2003;7:365-9.

8 Wilson JP, Chapman SW: Tuberculous mastitis. Chest 1990;98;1505-9.

9 Harris SH, Khan MA, Khan R, Haque F, Syed A, Ansari MM: Mammary tuberculosis: analysis of thirty-eight patients. ANZ J Surg 2006;76:234-7.

10 Sen M, Gorpelioglu C, Bozer M: Isolated primary breast tuberculosis: report of three cases and review of the literature. Clinics (Sao Paulo) 2009;64:607-10.
11 Al-Marri MR, Aref E, Omar AJ: Mammography features of isolated tuberculous mastitis. Saudi Med J 2005;26:646-50.

12 Zandrino F, Monetti F, Candolfo N: Primary tuberculosis of the breast. A case report. ActaRadiol 2000;41:61-3.

13 Kakker S, Kapila K, Singh MK, et al.: Tuberculosis of the breast. A cytomorphologic study. ActaCytol 2000;44:292-6.

14 Kanchanabat B, Kanchanapitak P, Thanapongsathorn W, Manomaiphiboon A: Fine-needle aspiration cytology for diagnosis and management of palpable breast mass. Aust N Z J Surg. 2000;70:791-4.

15 Romero C, Carreira C, Cereceda C, et al.: Mammary tuberculosis: percutaneous treatment of mammary tuberculous abscess. Eur Radiol 2000;10: $531-3$. 